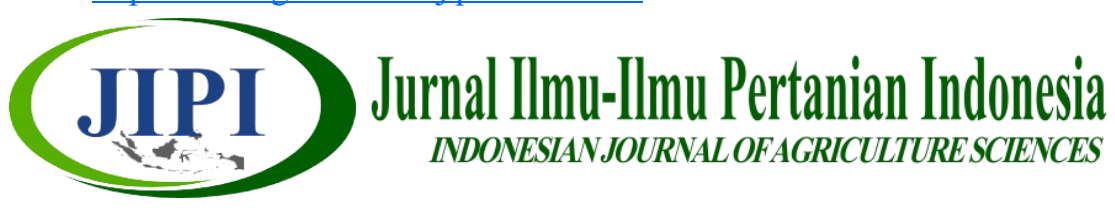

\title{
PENAMPILAN PERTUMBUHAN DAN HASIL LIMA HIBRIDA TOMAT PADA LAHAN ULTISOL DAN GAMBUT
}

\author{
Elpiana Purba ${ }^{1}$ Alnopri $^{{ }^{*}}$, Bandi Hermawan ${ }^{2}$, Helfi Eka Saputra ${ }^{1}$ \\ ${ }^{1}$ Program Studi Agroekoteknologi, Fakultas Pertanian Universitas Bengkulu \\ ${ }_{2}^{2}$ Program Studi Ilmu Tanah, Fakultas Pertanian Universitas Bengkulu \\ *Corresponding Author: alnopri_bkl@yahoo.co.id
}

\begin{abstract}
[GROWTH APPEARANCE AND YIELD OF FIVE TOMATO HYBRIDS ON ULTISOL AND PEATLANDS]. Ultisol and peat are included in marginal land that can support the growth and development of plants. This study was aimed to compare the growth and yield of five tomato hybrids on ultisol and peatlands. The experiments were carried out in the field with the soil type of on ultisol and peats. The experiment was arranged in a Randomized Completely Block Design with 3 replications. The hybrids evaluated were UNB-1 $\times$ UNB-2, UNB-3 $\times$ UNB-1, UNB-2 $\times$ UNB1 , and UNB-2 $\times$ UNB-3, and Sinta as a control hybrid. The results showed that in ultisol lands, the diversities among genotypes were observed in some variables, including the age of flowering, a number of fruits per plant, fruit diameter, fruit weight per plant, and fruit sweetness level. On the peatlands, a significant diversity was observed in plant height, age of flowering, age of harvest, fruit weight per plant, number of flowers per bunch. Based on this evaluation in the Ultisol soil, the yield of UNB2 $\times$ UNB1 was higher than control (Sinta genotype), whereas, in peat, the growth and yield components of UNB2 $\times$ UNB3 is the best and Sinta hybrid as a control genotypes showed the highest yield among other genotypes.
\end{abstract}

Keyword: genotype, peatlands, tomatoes, ultisol

\begin{abstract}
ABSTRAK
Ultisol dan gambut termasuk lahan yang marjinal untuk mendukung pertumbuhan dan dan perkembangan tanaman. Penelitian ini bertujuan untuk membandingkan pertumbuhan dan hasil lima hibrida tomat pada lahan ultisol dan gambut. Percobaan dilaksanakan pada lahan ultisol dan gambut yang masing-masing disusun dalam Rancangan Acak Kelompok Lengkap dengan 3 ulangan. Hibrida yang dievaluasi ialah UNB-1 $\times$ UNB-2, UNB-3 $\times$ UNB-1, UNB- $2 \times$ UNB-1, dan UNB-2 $\times$ UNB-3, dan Sinta sebagai hibrida pembanding. Pada lahan ultisol, keragaman antar genotipe dijumpai pada umur berbunga, jumlah buah/tanaman, diameter buah, bobot buah/tanaman, dan tingkat kemanisan buah. Pada lahan gambut diperoleh keragaman yang nyata pada tinggi tanaman, umur berbunga, umur panen, bobot buah/ tanaman, jumlah bunga/tandan. Berdasarkan hasil evaluasi terhadap genotipe-genotipe tersebut, pada hibrida UNB2 $\times$ UNB1 genotipe yang memiliki hasil lebih baik dari Sinta (kontrol) pada Ultisol, sedangkan pada gambut untuk pertumbuhan dan komponen hasil UNB2 $\times$ UNB3 merupakan genotipe yang terbaik, dan Sinta (kontrol) genotipe kontrol menunjukkan hasil yang lebih tinggi di antara genotipe yang lain.
\end{abstract}

Kata kunci: genotipe, tomat, ultisol, gambut 


\section{PENDAHULUAN}

Tomat (Lycopersicon esculentum Mill.) adalah komoditas hortikultura yang dapat digunakan sebagai sayuran, bahan baku industri obat-obatan dan kosmetik serta bahan baku olahan makanan (Wijayanti \& Susila, 2013). Gizi yang terkandung pada tanaman tomat sebanyak protein $(1 \mathrm{~g})$, kalori (20 kal), lemak $(0,3 \mathrm{~g})$, karbonhidrat $(4,2 \mathrm{~g})$, vitamin A (1500 SI), vitamin B (0,06 mg), vitamin C (40 mg), kalsium ( $5 \mathrm{mg}$ ), fosfor (26 mg), besi (0,5 mg), dan air (94 mg) (Purwati \& Khairunisa, 2007). Data statistik menunjukkan bahwa produksi tomat pada tahun 2014 sampai 2016 mengalami fluktuasi yaitu 916.001 ton/tahun, 877.801 ton/tahun, dan 883.242 ton/tahun. Sedangkan hal tersebut terjadi juga pada Provinsi Bengkulu yaitu 23.495 ton/ tahun, 21.084 ton/tahun dan 22.459 ton/tahun (BPS, 2017). Hal ini bertolak belakang dengan luasan lahan pertanian tomat di wilayah Bengkulu, yang luas lahannya tahun 2011 seluas 2530 ha dan pada tahun 2014 tercat seluas 3.198 ha.

Upaya meningkatkan produksi tomat untuk mencapai target yang telah ditetapkan dapat dilakukan melalui program intensifikasi dan ekstensifikasi pertanian. Program ekstensifikasi pertanian dihadapkan pada semakin terbatasnya lahan pertanian subur, sehingga untuk memenuhi kebutuhan tomat harus memanfaatkan lahan sub optimal (Haryono, 2013). Lahan yang sub optimal dan masih tersedia untuk pengembangan budidaya tomat adalah ultisol dan gambut. Ultisol mempunyai sebaran luas di wilayah indonesia mencapai 45,8 juta ha, meliputi hampir $25 \%$ dari total luas daratan di indonesia (Prasetyo \& Suriadikarta, 2006). Sedangkan lahan ultisol di Provinsi Bengkulu mencapai 706.00 ha atau $35,7 \%$ dari luasan wilayah Provinsi Bengkulu yaitu 1.978 .870 ha (BPTP Bengkulu, 2014). Menurut Sarief (1985) ultisol memiliki kendala yaitu kemasaman tanah tinggi, kapasitas tukar kation rendah, kejenuhan basa rendah, kandungan aluminium tinggi. Kendala dalam pengelolaan Ultisol adalah kandungan bahan organiknya yang sangat rendah yaitu kurang dari 2\% (Hanafiah, 2005). Bahan organik tanah menyusun sekitar 5\% bobot total tanah, meskipun hanya sedikit tetapi memegang peranan penting dalam menentukan kesuburan suatu tanah, baik secara fisik, kimiawi maupun secara biologis.

Jenis lahan yang masih tersedia untuk pengembangan tanaman tomat adalah lahan gambut. Gambut terbentuk dari timbunan sisa-sisa tanaman yang telah mati, baik yang sudah lapuk ataupun belum. Namun timbunan terus bertambah karena dekomposisi terhambat oleh kondisi aerob yang menyebabkan rendahnya perkembangan biota pengurai pada ekosistem tersebut. Sebaran lahan gambut di Indonesia berdasarkan aspek lingkungan mencapai 7.501 .630 ha hanya sekitar 29\% dari seluruh sebaran gambut yang ada di Indonesia (Tjahjono, 2006). Sebagai media bagi pertumbuhan tanaman tanah gambut memiliki kendala baik secara fisik maupun kimia. Kendala fisik meliputi penurunan muka tanah (subsidance), kering tidak balik (irreversible drying), daya dukung beban sangat rendah dan berubahnya sifat gambut menjadi anti air (hidrophobik) sementara secara kimia ( $\mathrm{pH}$ 2-3), peningkatan kadarkadar toksik seperti $\mathrm{Al}, \mathrm{Fe}, \mathrm{Mn}$, dan sulfida (Noor et al., 2014). Upaya lain yang dapat dilakukan untuk pengembangan tanaman tomat adalah penggunaan varietas yang unggul.

Menurut Roy (2000), varietas hibrida adalah generasi F1 dari sepasang atau lebih tetua inbred (galur murni) yang mempunyai sifat unggul. Baharudin et al. (2014), menyatakan bahwa faktor genotipe berpengaruh terhadap respon tanaman maka genotipe toleran memiliki aktifitas fotosintesis yang tinggi pada kondisi ternaungi sehingga akan menghasilkan fotosintat yang memadai untuk pertumbuhan dan produksi tanaman selain itu faktor lingkungan juga berpegaruh. Dalam strategi pemuliaan interaksi antara genotipe dengan lingkungan perlu diketahui terutama untuk mengetahui daya adaptasi suatu galur/ genotipe/ klon baru yang akan dikembangkan karena interaksi antara genotip dan lingkungan akan menghasilkan perbedaan ekspresi fenotifik yang berbeda pada lingkungan yang berbeda pula (Aribawa \& Kariada, 2014). Universitas Bengkulu telah menghasilkan genotipe tomat hibrida harapan yang diduga mempunyai daya hasil tinggi dan dapat beradaptasi baik pada dataran rendah. Lima genotipe hibrida di antarnya akan diuji pada lahan gambut dan ultisol. Adapun tujuan dari penelitian ini memperoleh genotipe tomat dengan pertumbuhan dan hasil terbaik pada lahan ultisol dan gambut.

\section{METODE PENELITIAN}

Penelitian ini dilaksanakan pada bulan Agustus sampai Oktober 2018, Di Desa Dusun Baru 1, Kecamatan Pondok Kubang, Kabupaten Bengkulu Tengah di Lahan Ultisol dan Gambut. Bahan dan alat yang akan digunakan pada penelitian ini antara lain bahan tanam adalah hibrida $F 1$ (yang terdiri atas genotipe $\mathrm{G} 1=\mathrm{UNB}-1 \times \mathrm{UNB}-2, \mathrm{G} 2=\mathrm{UNB}-3 \times \mathrm{UNB}-1, \mathrm{G} 3$ $=\mathrm{UNB}-2 \times \mathrm{UNB}-1, \mathrm{G} 4=\mathrm{UNB}-2 \times \mathrm{UNB}-3, \mathrm{G} 5=$ Sinta), Furadan $3 G$, pestisida, Pupuk NPK, dolomit dan pestisida. Cangkul, koret, meteran, gembor, jangka sorong, timbangan analitik, tali rafia, label, oven, kamera, dan alat tulis, tray semai, kertas label, ember, hand penetrometer, pisau, sprayer, penggaris, hand refractometer, dan knapsack sprayer.

Penelitian ini merupakan percobaan seri (Series Experimen) pada lahan ultisol dan gambut yang masing-masing disusun dalam RAKL faktor tunggal yaitu genotipe dengan tiga ulangan. Lima genotipe tomat disusun pada petak percobaan berukuran $1 \mathrm{~m}$ x $5 \mathrm{~m}$ dengan jarak tanam $50 \mathrm{~cm}$ x $50 \mathrm{~cm}$ 
dengan 3 ulangan. Pada setiap petakan terdapat lima genotipe tanaman dan masing-masing genotipe terdapat 10 tanaman, total seluruh tanaman adalah 50 tanaman, setiap genotipe diambil secara acak 5 tanaman sampel. Variabel yang diamati adalah tinggi tanaman, panjang daun, lebar daun, umur berbunga, umur panen, jumlah bunga/tandan, jumlah buah setiap tanaman, bobot buah/tanaman, bobot rata-rata buah, diameter buah, kekerasan buah, jumlah buah/ tandan, dan tingkat kemanisan buah. Data hasil pengamatan dianalisis menggunakan analisis varian (ANAVA) taraf 5\%. Perbandingan rata-rata antar perlakuan dilakukan dengan DMRT (Duncan's Multiple Range Test) pada taraf 5\%.

\section{HASIL DAN PEMBAHASAN}

Hasil analisis varians pada lahan ultisol menunjuk-kan bahwa lima genotipe tomat yang diuji memiliki keragaman yang nyata $(\mathrm{P} \leq 0,05)$ pada umur berbunga, jumlah buah/tanaman, diameter buah, dan tingkat kemanisan. Pada lahan gambut, keragaman yang nyata $((\mathrm{P} \leq 0,05)$ terdapat pada tinggi tanaman, umur berbunga, umur panen, dan jumlah bunga/ tandan (Tabel 1). Hal ini berarti bahwa secara umum genotipe diuji memiliki penampilan yang serupa untuk sebagian besar sifatnya. Adanya keragaman yang ditunjukkan oleh variabel-variabel tersebut maka dapat dilakukan pemilihan genotipe tomat yang potensial untuk dibudidayakan pada lahan ultisol dan gambut.

Tabel 1. Nilai $\mathrm{F}$ hitung genotipe pada lahan ultisol dan gambut

\begin{tabular}{|c|c|c|c|c|}
\hline \multirow{2}{*}{ Variabel } & \multicolumn{2}{|c|}{ F hitung } & \multicolumn{2}{|c|}{$\mathrm{KK}(\%)$} \\
\hline & Ultisol & Gambut & Ultisol & Gambut \\
\hline Tinggi tanaman & $2,51^{n s}$ & $20^{*}$ & 14,19 & 4,73 \\
\hline Panjang daun & $0,28^{\mathrm{ns}}$ & $3,24^{n s}$ & 18,99 & 12,5 \\
\hline Lebar daun & $0,39 \mathrm{~ns}$ & $0,59 \mathrm{~ns}$ & 22,25 & 12,3 \\
\hline Umur berbunga & $2,27^{\mathrm{ns}}$ & $8,5^{*}$ & 12,74 & 4,89 \\
\hline Umur panen & $2,66^{n s}$ & $4,53^{*}$ & 4,06 & 4,15 \\
\hline Jumlah buah/tandan & $1,82^{\mathrm{ns}}$ & $1,91 \mathrm{~ns}$ & 6,87 & 22,3 \\
\hline Jumlah buah/tanaman & $4,89^{*}$ & $3,15^{\mathrm{ns}}$ & 13,66 & 29,87 \\
\hline Bobot buah/tanaman & $10,91^{*}$ & $6,46^{*}$ & 11,1 & 30,01 \\
\hline Rata-rata bobot buah & $2,03 \mathrm{~ns}$ & $3,22 \mathrm{~ns}$ & 14,5 & 22,1 \\
\hline Diameter buah & $8,58 *$ & $1,87^{\text {ns }}$ & 8,38 & 15,5 \\
\hline Kekerasan buah & $0,83^{\mathrm{ns}}$ & $0,77^{\mathrm{ns}}$ & 7,45 & 5,35 \\
\hline Jumlah bunga/tandan & $3,19^{\mathrm{ns}}$ & $4,4^{*}$ & 7,33 & 10,1 \\
\hline Tingkat kema & $17,85^{*}$ & $2,33 \mathrm{~ns}$ & 4 & \\
\hline
\end{tabular}

Keterangan :* berpengaruh nyata $(\mathrm{P} \leq 0,05)$, ns berpengaruh tidak nyata $(P>0,05)$
Nilai koefisien keragaman (KK) tertinggi pada lahan Ultisol ditunjukkan oleh variabel lebar daun sementara nilai $\mathrm{KK}$ terendah pada variabel tingkat kemanisan buah. Nilai KK tertinggi pada lahan gambut ditunjukkan oleh bobot buah/tanaman sementara nilai KK terendah dimiliki oleh tingkat kemanisan buah. Hal tersebut menunjukkan bahwa lingkungan memberikan pengaruh yang bervariasi terhadap variabel yang diamati. Nilai KK menunjukkan tingkat ketepatan perlakuan, pengaruh lingkungan dan faktor lain yang tidak dapat dikendalikan oleh suatu percobaan (Gomez \& Gomez, 1995).

Perbedaan nilai tengah genotipe pada Ultisol dapat dilihat pada Tabel 2 dan Tabel 3. Perbedaan nilai tengah genotipe pada lahan gambut disajikan pada Tabel 4 dan Tabel 5.

Tabel 2. Nilai tengah genotipe pada lahan Ultisol

\begin{tabular}{|c|c|c|c|c|c|c|}
\hline \multirow{2}{*}{ Genotipe } & \multicolumn{6}{|c|}{ Variabel } \\
\hline & TT & $\mathrm{PD}$ & $\mathrm{LD}$ & $\mathrm{UB}$ & UP & $\mathrm{JBgPT}$ \\
\hline G1 & 51,91 & 19,08 & 14,08 & 35 & 62,67 & 7,26 \\
\hline $\mathrm{G} 2$ & 68,93 & 18,7 & 13,4 & 29,33 & 59 & 7,06 \\
\hline G3 & 59,66 & 20,3 & 15,46 & 32,33 & 63 & 6,66 \\
\hline G4 & 69,15 & 18,93 & 13,09 & 33 & 60 & 5,93 \\
\hline G5 & 72,06 & 21,43 & 12,6 & 29 & 57,67 & 6,73 \\
\hline
\end{tabular}

Tabel 3. Nilai tengah genotipe pada lahan Ultisol

\begin{tabular}{c|c|c|c|c|c|c|c|}
\hline & \multicolumn{7}{|c|}{ Variabel } \\
\cline { 2 - 8 } Genotipe & JBST & BBPT & BRRB & DB & KB & JBPT & TKB \\
\hline G1 & $17,9 \mathrm{c}$ & $653,3 \mathrm{~d}$ & 23,2 & $28,3 \mathrm{bc}$ & 1,18 & 6,38 & $5,30 \mathrm{a}$ \\
\hline $\mathrm{G} 2$ & $26,2 \mathrm{a}$ & $905,9 \mathrm{bc}$ & 21,8 & $25,4 \mathrm{c}$ & 1,15 & 5,86 & $4,43 \mathrm{~b}$ \\
\hline $\mathrm{G} 3$ & $25 \mathrm{ab}$ & $1039 \mathrm{ab}$ & 21,1 & $25,3 \mathrm{c}$ & 1,23 & 6,3 & $4,32 \mathrm{~b}$ \\
\hline G4 & $18,8 \mathrm{c}$ & $834,2 \mathrm{~cd}$ & 28,1 & 32,9 ab & 1,23 & 6,35 & $5,09 \mathrm{a}$ \\
\hline $\mathrm{G} 5$ & $19,8 \mathrm{c}$ & $1162 \mathrm{a}$ & 25,6 & 34,2 a & 1,28 & 5,8 & $4,35 \mathrm{~b}$ \\
\hline Keterangan : Angka-angka yang diikuti oleh huruf yang sama pada kolom yang \\
sama berbeda tidak nyata pada DMRT 5\%. JBST=jumlah buah setiap tanaman; \\
BBPT = bobot buah/tanaman; BRRB = bobot rata-rata buah; DB = diameter buah; \\
KB = kekerasan buah; JBPT = jumlah buah per tandan; TKB = tingkat kemanisan
\end{tabular}

Tinggi tanaman pada genotipe-genotipe tomat yang diuji pada lahan gambut berkisar antara 38,49 sampai 54,00 (Tabel 4). Genotipe G5 adalah genotipe yang memiliki nilai tengah tertinggi $54.00 \mathrm{~cm}$ berbeda tidak nyata terhadap genotipe G1, G2, G3, dan G4. Nazirwan et al. (2014) menambahkan bahwa perbedaan tinggi tanaman dipengaruhi oleh faktor genetik dari masing-masing galur/nomor dan lingkungan seperti intensitas cahaya, temperatur dan ketersediaan unsur hara. Pertumbuhan tinggi tanaman menunjukkan pembentukan xilem dan pembesaran 
sel-sel yang tumbuh (Wasonowati, 2011). Aktivitas ini menyebabkan kambium terdorong keluar dan terbentuknya sel-sel baru di lapisan tersebut sehingga terjadi peningkatan tinggi tanaman.

Tabel 4. Nilai tengah genotipe pada lahan gambut

\begin{tabular}{|c|c|c|c|c|c|c|c|}
\hline \multirow{2}{*}{ Genotipe } & \multicolumn{7}{|c|}{ Variabel } \\
\hline & TT & $\mathrm{PD}$ & & $\mathrm{LD}$ & UB & UP & $\mathrm{JBgPT}$ \\
\hline G1 & $38,49 \mathrm{c}$ & 15,86 & $a b$ & 13,48 & $30,00 \mathrm{a}$ & $54,38 \mathrm{a}$ & 5,26 \\
\hline G2 & $45,20 \mathrm{~b}$ & 17,87 & a & 12,98 & $26,06 \mathrm{~b}$ & $49,7 \mathrm{~b}$ & 4,81 \\
\hline G3 & $47,36 \mathrm{~b}$ & 17,35 & a & 14,18 & $30,06 \mathrm{a}$ & 57,38 a & 5,88 \\
\hline G4 & $44,36 \mathrm{~b}$ & 17,28 & a & 14,42 & $32,13 \mathrm{a}$ & $54,44 \mathrm{a}$ & 5,23 \\
\hline G5 & $54,00 \mathrm{a}$ & 12,67 & b & 12,67 & 32,13 a & $54,53 \mathrm{a}$ & 6,55 \\
\hline
\end{tabular}

Keterangan : Angka-angka yang diikuti oleh huruf yang sama pada kolom yang sama berbeda tidak nyata pada DMRT 5\%,TT = tinggi tanaman, $\mathrm{PD}=$ panjang daun; $\mathrm{LB}=$ lebar daun; $\mathrm{UB}=$ umur berbunga; $\mathrm{UP}=$ umur panen; JBgT = jumlah bunga/tandan

Pada jumlah buah setiap tanaman di lahan ultisol, genotipe G2 memiliki angka sebesar 26,25 (Tabel 3) dan berbeda nyata dengan G1, G4, G5 serta berbeda tidak nyata dengan G3. Namun demikian, di lahan gambut tidak terdapat perbedaan genotipe untuk variabel jumlah buah setiap tanaman (Tabel 5). Zdravkovic et al. (2011) menambahkan bahwa jumlah buah/tanaman merupakan sifat kuantitatif yang dikendalikan oleh banyak gen dan sangat tergantung pada lingkungan. Rendahnya jumlah buah disebabkan oleh kurangnya nitrogen yang dapat ditransfer untuk pembentukan buah, selain itu rendahnya jumlah buah juga disebabkan karena banyaknya jumlah bunga yang rontok akibat curah hujan yang tinggi pada fase generatif (Dermawan, 2006). Untuk variabel bobot buah/tanaman, genotipe G3 yang diuji di lahan ultisol memiliki bobot buah/ tanaman setara dengan genotipe G5 yang digunakan sebagai pembanding (Tabel 3). Selanjutnya, genotipe G5 memiliki bobot buah/tanaman tertinggi dibandingkan semua genotipe yang diuji pada lahan gambut (Tabel 5). Genotipe G5 memiliki keragaan terbaik untuk bobot buah/tanaman di ultisol dan gambut sehingga pemilihan genotipe ini sebagai pembanding sudah tepat. Sedangkan untuk genotipe G3, ada perbedaan keragaan antara lokasi tanam pada lahan ultisol dan gambut. Pada lahan ultsiol, genotipe G3 dapat menunjukkan keragaan yang baik sehingga bisa setara dengan genotipe G5. Namun demikan, pada lahan gambut genotipe G3 tidak dapat menunjukkan keragaan yang setara dengan genotipe G5 sehingga genotipe G3 bisa direkomendasikan hanya pada lahan ultisol.

Diameter buah genotipe G5 memiliki angka diameter buah terbesar yaitu 34,22 $\mathrm{mm}$ (Tabel 3) dan berbeda nyata dengan G1, G2, dan G3, tetapi berbeda tidak nyata dengan G4 pada lahan ultisol. Selanjutnya pada lahan gambut, tidak terdapat perbedaan diameter buah pada semua genotipe yang diuji (Tabel 5). Terjadi perbedaan diameter buah pada penelitian ini hal ini dipengaruhi oleh genetik tanaman untuk menghasilkan buah dalam ukuran yang besar ataupun kecil. Mangoendijojo (2008) menyatakan bahwa sifat ukuran tomat dikendalikan secara kuantitatif oleh banyak gen walaupun tanaman tersebut ditanam pada situasi lingkungan yang sama apabila terjadi perbedaan tersebut merupakan perbedaan yang berasal dari gen individu anggota populasi. Hasil penelitian Situmorang et al. (2014) menunjukkan bahwa genotipe IPB T34-7-7 mempunyai diameter yang paling besar yaitu $3.42 \mathrm{~cm}$. Keberagaman diameter buah tomat disebabkan oleh faktor gen dan lingkungan (Suryadi et al., 2004).

Tabel 5. Nilai tengah genotipe pada lahan Gambut

\begin{tabular}{|c|c|c|c|c|c|c|c|c|}
\hline \multirow{2}{*}{ Genotipe } & \multicolumn{8}{|c|}{ Variabel } \\
\hline & JBS & & ВBPT & BRRB & DB & $\mathrm{KB}$ & JBPT & TKB \\
\hline G1 & 17,9 & c & $653,3 \mathrm{~d}$ & 23,2 & $28,3 \mathrm{bc}$ & 1,18 & 6,38 & $5,30 \mathrm{a}$ \\
\hline G2 & 26,2 & a & $905,9 \mathrm{bc}$ & 21,8 & $25,4 \mathrm{c}$ & 1,15 & 5,86 & $4,43 \mathrm{~b}$ \\
\hline G3 & 25 & & $1039 \mathrm{ab}$ & 21,1 & $25,3 \mathrm{c}$ & 1,23 & 6,3 & $4,32 \mathrm{~b}$ \\
\hline G4 & 18,8 & c & $834,2 \mathrm{~cd}$ & 28,1 & $32,9 \mathrm{ab}$ & 1,23 & 6,35 & $5,09 \mathrm{a}$ \\
\hline G5 & 19,8 & c & $1162 \mathrm{a}$ & 25,6 & 34,2 a & 1,28 & 5,8 & $4,35 \mathrm{~b}$ \\
\hline \multicolumn{9}{|c|}{$\begin{array}{l}\text { Keterangan : Angka-angka yang diikuti oleh huruf yang sama pada kolom } \\
\text { yang sama berbeda tidak nyata pada DMRT } 5 \% \text {. JBST=jumlah buah setiap } \\
\text { tanaman; BBPT = bobot buah/tanaman; BRRB = bobot rata-rata buah; } \mathrm{DB}= \\
\text { diameter buah; KB = kekerasan buah; JBPT = jumlah buah per tandan; } \mathrm{TKB}=\end{array}$} \\
\hline
\end{tabular}

Tingkat kemanisan buah diukur menggunakan alat hand refractometer ketika buah tomat pada fase red (90\% permukaan buah berwarna merah). Pada lahan ultisol, genotipe G1 dan G4 memiliki tingkat kemanisan buah paling besar dibanding dengan dengan G2, G3, dan G5. Selanjutnya untuk lahan gambut, semua genotipe yang diuji tidak memiliki perbedaan untuk variabel tingkat kemanisan buah (Tabel 5). Kandungan kemanisan buah dari se-tiap genotipe yang diteliti memiliki nilai yang berkisar dari 4,3 sampai 5,3 brix. Kandungan kemanisan buah terlarut dari setiap genotipe yang diteliti memiliki nilai yang berkisar dari 4 sampai 8 brix (Hayati, 2014). Menurut Jones (2007) tomat berukuran kecil seperti tomat ceri pada umumnya mempunyai nilai Brix lebih tinggi (antara 6-8) sedangkan tomat ukuran lebih besar mempunyai nilai Brix lebih rendah antara (4-6). Melly et al., (2012) menambahkan bahwa, semakin masak tomat maka semakin tinggi nilai total padatan terlarutnya. Hal ini diduga karena selama proses pematangan kandungan gula di dalam tomat terus meningkat yang disebabkan karena terjadinya degradasi pati (karbohidrat) menjadi gula sederhana (glukosa dan fruktosa) sehingga kandungan gulanya meningkat.

Umur berbunga genotipe-genotipe tomat yang diuji pada lahan gambut memiliki nilai tengah yang berkisar antara 26,06 hst-32,12 hst (Tabel 4). Genotipe yang memiliki umur berbunga yang paling cepat adalah genotipe G2. Namun demikian, pada lahan ultisol tidak ada perbedaan antar genotipe untuk umur berbunga (Tabel 2). Narziwan et al. (2014) dalam penelitiannya 
menunjukkan seluruh galur tomat yang diuji memiliki umur berbunga 28-31 hst sehingga genotipegenotipe yang diuji pada penenlitian ini juga menunjukkan penampilan yang sama. Perbedaan umur berbunga pada tiap tanaman dapat terjadi akibat pengaruh suhu, cahaya dan unsur hara yang diserap oleh tanaman (Arnanto et al., 2013). Pada lahan gambut, terdapat perbedaan antar genotipe untuk variabel umur panen (Tabel 5), sedangkan pada lahan ultisol tidak demikian. Umur panen genotipe-genotipe tomat yang diuji pada lahan gambut memiliki nilai yang berkisar antara 49,70-57,38 hst (Tabel 4). Genotipe G2 merupakan genotipe yang memiliki umur panen paling cepat yaitu $49.70 \mathrm{hst}$ dibandingkan dengan semua genotipe lainnya. Umur panen yang cepat pada genotipe G2 disebabkan genotipe ini cepat berbunga dibandingkan dengan genotipe lainnya (Tabel 4).

\section{KESIMPULAN}

Genotipe G5 memiliki keragaan bobot buah/ tanaman terbaik untuk lahan ultisol dan gambut. Genotipe G3 memiliki keragaan bobot buah/tanaman terbaik hanya untuk lahan ultisol.

\section{SANWACANA}

Ucapan terima kasih disampaikan kepada Kementerian Riset dan Pendidikan Tinggi yang sudah mendanai penelitian ini melalui Penelitian Produk Terapan berdasarkan Surat Keputusan Nomor 3/E/ KPT/2018 dengan perjanjian/Kontrak Nomor 561/ UN30.15/LT/2018 serta semua pihak yang telah membantu.

\section{DAFTAR PUSTAKA}

Aribawa, I. B. \& Kariada, I.K. (2014). Adaptasi Beberapa Galur Tomat (Lycopersicum esculentum Mill.) di Lahan Medium Beriklim Basah di Bali dengan Budidaya Organik. Prosiding Seminar Nasional Pertanian Organik,18-19 Juni 2014. Bogor.

Arnanto, D., Basuki, N. \& Respatijarti. (2013). Uji toleransi salinitas terhadap sepuluh genotip F1 tomat (Solanum lycopersicum L.). Jurnal Produksi Tanaman, 1(5), 415-421.

Badan Pengkajian Teknologi Pertanian Bengkulu. 2014. Pemanfaatan Lahan Kering Masam dengan Tumpang Sari Jagung dan Kacang Tanah di Provinsi Bengkulu. Balai Pengkajian Teknologi Pertanian Bengkulu, Bengkulu.

Badan Pusat Statistik \& Direktorat Jendral Hortikultura. (2017). Data Produksi Tomat Nasional. http:/ bps.go.id.

Baharuddin, R., Chozin, M.A \& Syukur, M. (2014). Toleransi 20 genotipe tomat terhadap naungan. Jurnal Agro Indonesia, 42(2), 130-135. DOI: https://doi.org/10.24831/jai.v42i2.8431 .
Dermawan, E. (2006). Kajian Daya Hasil Tiga Varietas Cabai Merah Besar (Capsicum annuum L.) Akibat pemberian jenis pupuk. Skripsi. Fakultas Pertanian. Universitas Jember, Jember.

Gomez K.A. \& Gomez, A.A. (1984). Statistical Prosedures for Agricultural Research. Diterjemahkan oleh Syamsudin E, Baharsyah JS, (1995). Prosedur Statistik untuk Penelitian Pertanian. UI Press, Jakarta.

Hanafiah, K. A. (2005). Dasar-dasar Ilmu Tanah. PT. Raja Grafindo Persada, Jakarta.

Haryono. (2013). Srategi Kebijakan Kementerian Pertanian Dalam Optimalisasi Lahan Suboptimal Mendukung Ketahanan Pangan Nasional. Hlm1- 4 DalamProsiding Seminar Nasional Lahan Suboptimal "Intensifikasi Pengelolaan Lahan Suboptimal Dalam Rangka Mendukung Kemadirian Pangan Nasional". Palembang, 2021 September 2013.

Hayati, D. (2014). Karakterisasi Morfologi dan Fisiologi 15 Genotipe Tomat (Solanum lycopersicum L.). Skripsi. Universitas Bengkulu, Bengkulu. (tidak dipubliskan)

Jones J.B. (2007). Tomato Plant Culture In The Field, Greenhouse, and Home Garden. CRC Press., New York.

Mangoendidjojo, W. (2008). Pengantar Pemuliaan Tanaman. Kanisius, Yogyakarta .

Melly, N., Satriana \& Martunis. (2012). Pengaruh pelampiasan kitosin terhadap sifat fisik dan kimia tomat segar (Lycopersicum pyriforme) pada berbagai tingkat kematangan. Jurnal Teknologi dan Industri Pertanian Indonesia, 4 (3), 1-8.

Narzirwan, Wahyudi, A. \& Dulbari. (2014). Karakterisasi koleksi plasma nutfah tomat lokal dan introduksi. Jurnal Penelitian Pertanian Terapan, 14(1), 70-75. DOI: http://dx.doi.org/10.25181/jppt. v14i1.144

Noor, M., Nursyamsi, D., Alwi, M. \& Fahmi, A. (2014). Prospek pertanian berkelanjutan di lahan gambut: dari petani ke peneliti dan peneliti ke petani. Jurnal Sumberdaya Lahan, 8(2), 69-79. DOI: http://10.2018/jsdl.v8i2.6469.

Prasetyo, B. H. \& Suriadikarta, D.A. (2006). Karakteristik, potensi, dan Teknologi pengolahan tanah Ultisol untuk pengembangan pertanian lahan kering di Indonesia. Jurnal Litbang Pertanian, 25(2), 39-47.

Purwati, E. \& Khairunisa. (2007). Budidaya Tomat Dataran Rendah dengan Varietas Unggul serta Tahan Hama dan Penyakit. Penebar Swadaya, Jakarta.

Roy, D. (2000). Plant Breeding, Analysis and Exploitation of Variation. Narosa Publishing House, New Delhi, India. 
Sarief, E. S. 1985. Pupuk dan Cara Pemupukan Tanah Pertanian. Pustaka Buana, Bandung.

Situmorang, A., Adiwirman \& Deviona. (2014). Uji pertumbuhan dan daya hasil enam genotipe tomat (Lycopersicum esculentum Mill) di dataran rendah. Skripsi. Universitas Riau, Riau.

Suryadi, Luthfy, Yenni , K. \& Gunawan. (2004). Karakterisasi koleksi plasma nutfah tomat lokal dan introduksi. Bul. Plasma Nutfah. 10(2), 7276.

Tjahjono, J. A. E. (2006). Kajian Potensi Endapan Gambut Indonesia Berdasarkan Aspek Lingkungan. Proseding Pemaparan Hasil-hasil Kegiatan Lapangan dan Non Lapangan Tahun 2006, Pusat Sumberdaya Geologi.
Wasonowati, C. (2011). Meningkatkan pertumbuhan tanaman tomat (Lycopersicom esculentum Mill.) dengan sistem budidaya hidroponik. Jurnal Agrovigor, 4(1), 27-28

Wijayanti, E. \&. Susila, A.D. (2013). Pertumbuhan dan produksi dua varietas tomat (Lycopersicum esculentum Mill.) secara Hidroponik dengan beberapa komposisi media tanam. Buletin Agrohorti, 1(1), 104-112. DOI: https:// doi.org/10.29244/agrob.1.1.104-112 .

Zdrakovic, J., Pavlovic, N., Girek, Z, Brdr-Jokanovik, M, Savic, D., Zdrakovic, M, \& Cvikic, D. (2011). Generation mean analysis of yield components and yield in tomato (Lycopersicon esculentum Mill.). Pak. J. Bot 43(3), 1575-1580. 